\title{
MINERALS IMBALANCE AS A FIELd PROBLEM IN CALVES
}

\author{
Nehad A. B. and Eman Sh. M. L. \\ Biochemistry Department. Animal Heailh Research lnslilule. Dolikı. Eluypl
}

\begin{abstract}
Senim samples were collected from 14 calves of different nges suffiering from unorevia, loss of body weight, depression, recumbency alopacia and diarmea. Fstimation of serum minerals revealed increase in calcium. phosphorus and zinc concentration. as well as decreased levels of magnesium, sodium and potassium in serwn uhile those of copper and iron were in the normal physiological value. Examination of ration somples revealed decrease in protein content and increuse in calcium. phosphonss, and iron levcls While, magnesiunt, copper and zinc lewels were adequate to cover requirement of calves. Also, acid number was high indicaled oxidalive rancidily of the rulion.

The mineral inbalance state of ration in addition to rancidiuy uiere suggested to be the real cause of the problem as the symptoms were subsided when the ration was replaced by a new one.
\end{abstract}

\section{INTRODUCTION}

Calf is considered to be the primary producing unit in the beef industiy. Feeding of calves is of special interest because of the high economic losses from carly diseases problem and death. Feeding of calves encounters many problems in Egypt and many conntries of similar condition. thesc problems malnly associated with mineral imbalanced ratlon. As the mincral are required to metabolize the energy and protein portion of ration. Nlhough the cattle's body contains a large number of minerals, only 15 can be eonsidered essential sodium, ehloride. iodine. manganese. iron. copper, cohalt. zinc. calclum, phosphorus. potassium. magnesium, sulfur molybdcnum and selenium (Pope, 1972).

Livestnck obtaln mincrals primally from two sources thosc contained in feed ingredients and from mincral supplements. Watcr may or may not provide a source while, ais rarely contributes any significant amount (Relth, 1985). The misuge of mincral supplements by pruducers. marufacturers and the user of livestock ration may lead to many feed problems duc to imbalanced mineral ration. The miveral content of the feed is only a guideline to the mineral status of the arlunal. In eertain instanees, this information can be quite helplul but it needs to be combined 
with clinical and pathological examinations of the animals. Likewise. deficiency syinptoms also can be served as guidelines since many symptonis are nol chararteristic of a single mineral inadequacy. So, It would seem that one of the most valuable aids in detcction of mineral deficiencies or excess is blood analysis.

On the other hand, storage of feed stufts for a long perind of lime especially under local bad environmental conditions of high temperature and humidity exposes these feeds to delerioralinn s and losses of thetr mutritive values. The most common problem met wilk during sturage is autoxidation. Autoxkdation is the chenlcal manifestation of raneidity which has been incriminated in the impalment of many biochemical and physiological lunction in animals resulting in redused feed inlake, poor perlonnanee, depressed growth, diarrhea and altered protein utllization (Carpenter et al., 1963). No avallable literature regarding the effect of mineral imbalance and rancid ration on performance of calves, for this reason, this investigation was carried out to elucidate the role of rancidity and dietary minerals as probable factors affecting performanee of calves.

\section{MATERIALS AND METHODS}

\section{Animals and Ration : -}

Fourteen Friesian ealves of different ages in a herd in private farm in Isinaelia Governrate wcre reported to have loss of appetite, decrease in body weight and diarrlura. Calves were al lowed lo dict composed of concentrated ration. to which was added forage and hay ration. chemical analysis revealed that it contalned $12.51 \%$ protcin. $2.81 \%$ \%at. $0.7 \%$ calcium, $0.53 \%$ phosphors, $0.29 \%$ magnesium, $0.45 \%$ copper, $7.4 \%$ iron and $0.14 \%$ zinc whlle the acid number was 179.

Close clinical examination revealcd weakness, anorexia deprived appetite. loss of hody weight. alupecia. dtarthea and recumbency. Temperature, respiration and plus were not altered. Clinical exainination revealed no parasitic infcclton. There was no response to antibiotic therapy.

\section{Samples : -}

Scrum samples were obtained for determination of mineral profile in calves. Concentration of magnesium. iron, coppcr and zinc werc deterinined by atomie absorption spcctrophotometer ac:cording to methods Jescribed by manufacturer (Perkin Elmer, 1973). Calcium concentration measurcd according to Glngler and King (1973) while Inorganlc phosphorus was measurcd as described by kllchling and Freiburg (1951). Sodluni and potassiuin were detennincd according to Burriel and Ramtrez (1957). 
Ration samples were analyzed for determination of crudc protcin (Oser, 1979). acid numbci. for liydrolytic and oxddative raneldity (Koch and Hank, 1953). Also, ration samples werc analyzed for determination of calelum, Inorganic phosphorus, magnesium, copper, iron and zinc concentration.

Control for both serum samples (14 apparently healthy aninals) and ialion sanple lone lresh sample) were simultancously analyzed and statistically operated with the test samples according (o Petrle and Watson (1999).

\section{RESULTS AND DISCUSSION}

The matr clinical features of the affected animals were authenticatcd by lalsoratory analysis of both scrum and ration Table (I) which revcaled signifleant increasc in concentration of calcium. phosphorus and zinc while there was significant decrease in concentration of magnesium, sodium and potassium. On the other hand, there was no physiological change in concentration of botl copper and iron of the diseased animal when comparcd with control one.

Ration analysis was tabulated in table 2, it revcaled decreased levcl of crude protcin, ancl increased value of acid number as an indication of oxidalive rancidity. The concentration of cal. cium. phosphorus and iron were higher than normal value in control sample (firesh sample). $\Lambda$ clecrease in the Icvels of magncsium. copper and zinc concentration was also detccted .

Minerals are of major ceonomlc importance in calves and cattlc and arc intimatcly conecrned with optimal heditt and performancc (Radostits et al., 1995). The deficicncy symptoms of minerals was not characteristic of a single mineral inalequency as the main mixcral dcliciency symptoms were anorexia, loss of body weight. weakness. reeombancy and miglut be cliarrheia. The same clinical features were reported in our investigation.

scrum caleium level showed signifleant increase as a rcsult of fceding animals on excess calclum and unbalanced ca/p ratlo. The obtained results were in accordance wilh those reported by Doxey (197 1). Serum phosphons levcl showed significant lncreasc as ration contain excess phosphorus. De-Boer et al., (1981) reported that excesslve phosphorus intake elevatcd plasma phosphorus and may cause bone resorption and urinary troubles.

Rcsults rcvealed seruin hypo magnesla although ration analysis revealed adequate level of magneslum that was sufficient to cover all animals necds and at the same tins present orrurrence of hypornagncsaemic tetany. This finding rendered the cxact cause of thit condition ('nigmalic and aroused controversial confusion as reportcd by Kaneko (1989): Meyer et al.,( 1992) and Duncan et al., (1994) 
Serum zinc. concentration slightly incrcascd although zinc levcl in ration was within nornal value. DeBoer et al., (1981) reported that level of zinc in ration has direct effect on serum zinc level.

Concentration of both iron and copper in serum was in the normal physiological level while in ratlor were adcquate to cover anlmal maintenance.

Both sodium and potassium concentration were decreascd which might be clue to diarrliea and electrolyte loss. (Ramadan et al, 1985).

Kelly (1984) recorded that animals recelved rancid fat in ration showed allects which might be Include appetite and growth depresslon, diarrhea alopecia, gencral morbidity same. So. the cllect of rancidity and ration mineral imbalance may combine to form the elinieal symptoms recorded in this Investigation.

From the above results. It is obvious that there is a great relationship between inineral content of the feed and the nineral status of the antmat. Niso. there is a direct effect ul minneral inbellance in ratton and rancidity of fat. 
Nehad A. B. and Eman Sh. M. L.

Table 1 : Serum analysis of diseased and control animass.

\begin{tabular}{|c|c|c|c|c|c|c|c|c|}
\hline Animal Parameter & $\begin{array}{c}\mathrm{Ca} \\
\mathrm{Mg} \%\end{array}$ & $\begin{array}{c}\mathrm{P} \\
\mathrm{Mg} \%\end{array}$ & $\begin{array}{c}\mathrm{Mg} \\
\mathrm{Mg} \%\end{array}$ & $\begin{array}{c}\mathrm{Zn} \\
\mathrm{Mg} \%\end{array}$ & $\begin{array}{c}\mathrm{Fc} \\
(\mathrm{mg} / \mathrm{dl})\end{array}$ & $\begin{array}{c}\mathrm{Cu} \\
\text { (mg/l) }\end{array}$ & $\begin{array}{c}\mathrm{Na} \\
\mathrm{Mg} \%\end{array}$ & $\begin{array}{c}\mathrm{K} \\
\mathrm{Mg} \%\end{array}$ \\
\hline Diseased & $12.3 \pm 0.89$ & $6.8 \pm 1.05$ & $1.71 \pm 0.20$ & $0.11 \pm 0.04$ & $89.3 \pm 1.20$ & $73.0 \pm 5.30$ & $261.1 \pm 6.81$ & $61.2 \pm 0.81$ \\
\hline Control & $9.7 \pm 0.26$ & $3.6 \pm 0.79$ & $2.65 \pm 0.11$ & $0.07 \pm 0.01$ & $83.0 \pm 3.23$ & $64.2 \pm 3.79$ & $311.0 \pm 8.58$ & $34.3 \pm 3.43$ \\
\hline
\end{tabular}

LSD at $P<0.05$

Table 2 : Analysis of ration ollered to diseased animals compared with fresh one (control).

\begin{tabular}{|c|c|c|c|c|c|c|c|c|c|}
\hline $\begin{array}{c}\text { Parameler } \\
\text { Ralion }\end{array}$ & $\begin{array}{c}\text { Prolein } \\
\%\end{array}$ & $\begin{array}{c}\text { Fat } \\
\%\end{array}$ & $\begin{array}{c}\text { Acid } \\
\text { No. }\end{array}$ & $\begin{array}{c}\text { Ca } \\
\%\end{array}$ & $\begin{array}{c}\text { Pn } \\
\%\end{array}$ & $\begin{array}{c}\text { Mg } \\
\%\end{array}$ & $\begin{array}{c}\text { Cu } \\
\%\end{array}$ & $\begin{array}{c}\mathrm{Zn} \\
\mathrm{mg}\end{array}$ & $\begin{array}{c}\text { Fe } \\
\%\end{array}$ \\
\hline Diseased & 12.51 & 2.81 & 1.79 & 0.97 & 0.73 & 0.29 & 0.45 & 0.14 & 7.4 \\
\hline Control & 17.21 & 2.56 & 10.0 & 0.89 & 0.61 & 0.39 & 0.50 & 0.20 & 4.00 \\
\hline
\end{tabular}




\section{REFERENCES}

Burriel. M. and Ramirez, M. (1957) : Manual of Flame. Photometrically. Flame Photometry Jheory and Application. Anerican Elscyler Publishing Co. Inc. New York.

Carpenter, K. J.; Lea, C. H. and Parr, L. J. (1963) : Chemical and nutritional changes in stored herring meal. (4) Nutritional significance of oxidation of the oil. British. J. Nutr. 17. 151 .

DeBoer, G.; Buchanan-9mith, J. G.: MaClead, G. K. and Walton, J. B. (1981) : Responses of dairy cows fed alfalla silage supplemented with phosphorus, cupper. anc and manganese. J. Dairy Sci. 64. 2370.

Doxeg, D. L. (1971) : Velertnary Clinical Pathology. Bailliere Tindall, London, Wiltiaıns Wilkıns Company. Balumore.

Duncan, J. R.; Keith. W. P. and Edwerd. A. M. (1994) : Veterinary Laboratory Medicine and Clinical Pathology 3rd cd. lowa State Untversity Press. Ames, lovia USA.

Gingler. E. M. and King, J. D. (1973) : Rapid Colornetric determinatinn of calcium in biological fluids with methylene bluc. Nn. J. Clin. Pall., 58, 367.

Kaneko. J. J. (1989) : Clinical BJochemistry of Dumestic Ani/nals. $4^{\text {th }}$ ed. Acade.nic Press Inc. Sandiago. Ncw York. 335-365.

Kelly, w. R. (1984) : Velerinary Clinlcal Diagnosls. $3^{\text {rd }}$ ed. Bailliere Jindall, Loridon.

Kulching, H. and Frelburg, B. (1951) : Inorganic phosphurus and alkallne phospliatase in serum. In "Clintcal Hholometry" 3rd ed. Wiss. Verl. Ges. Mbit Stutgart.

Koch, F. C. and Hank, M. E. (1953) : Practical Merhods In Blochemistry. $6^{\text {th }}$ ed. Ballimore. The Williams and Wilkins Company.

Meger, D. J.; Embert, H. C. and Lon, J. R. (1992) : Veterinary Laboratory Medicinc Interpretation And Diagnosis. W.B. Saunders Cumpany. LSA.

Oser, B. L. (1979) : Hawk s Physiolnglcal Chemistry. $14^{\text {th }}$ ed. Tata Me-Craw Hill Publishing Company Lte. New Delhy.

Perkln-Elmer. (1973) : Analytical methods for atomk absorption spectrophotometry . PerkinElmes Crop., Norwalk. C.T.

Petrie, A. and wateon, P. (1999): "Stallstics for Veterinary and Animal Selenee"; Ist Ed.. p). 90. 99. The Blackwell Seicnee Ltd. United Acadenitc I'ress. New York.

Pope, A L. (1972) : A Revlew of Recent Mincrals Research with Ruminants. d. Anim. Dary Sri 
$33(6): 1332-1343$.

Radogtits,O. M.; Blood. D. C. and Gay. C. C. (1995) : Veterinary Medicine. $8^{\text {th }}$ ed. Bailliere. Tindal, London, Philadelphia,

Ramadan, S. A. Abu Zeld, A. A.; Hussien, M.; Itman, R. H.; El-Neweehy, T. K. and Arab, R. M. (1985) : Studies on some enzymatic and acid-base disturbances in Egyptian bulfalo calves suffering from entritls. J. Egypt. Vet. Med. Ass. 45 (1) : 175-181.

Relth, J. W. S. (1986) : Soil factors influeneing the trace element content of herbage. ln C.F. Mills (Ed.) Trace element metabolisin in animals. E.7S. Livingstone. Edinhulgh and London. PP.410-412. 


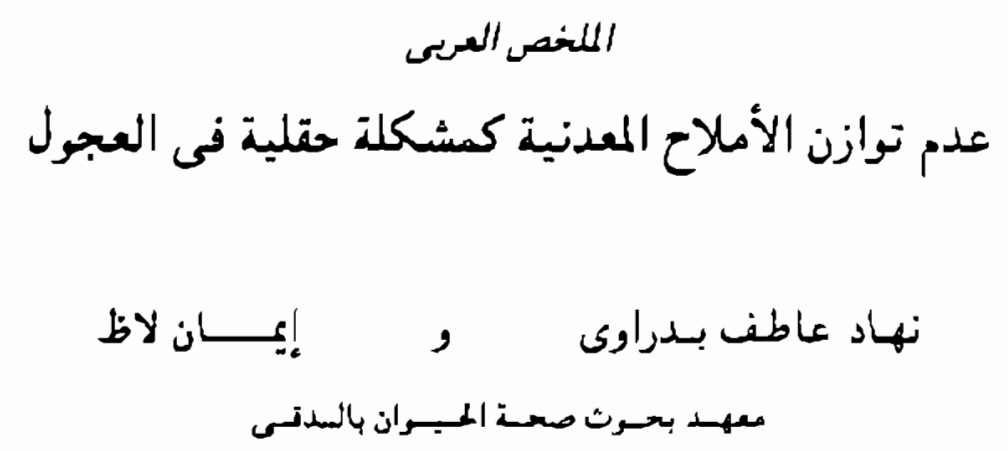

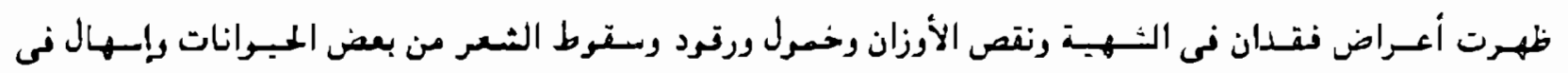

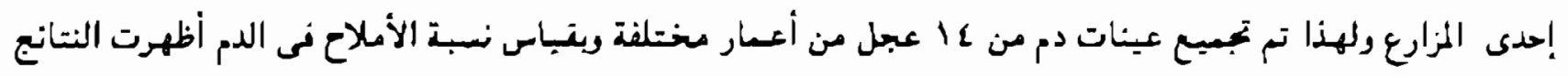

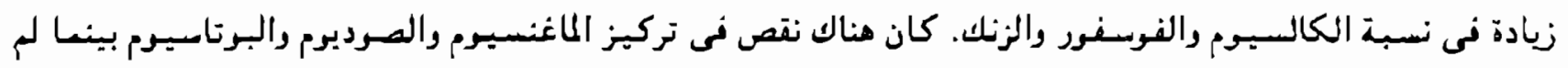

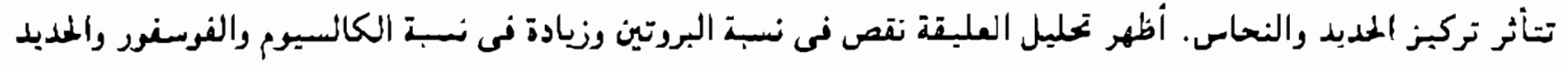

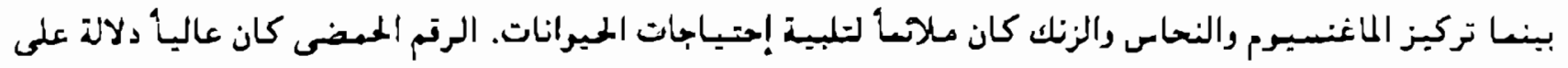

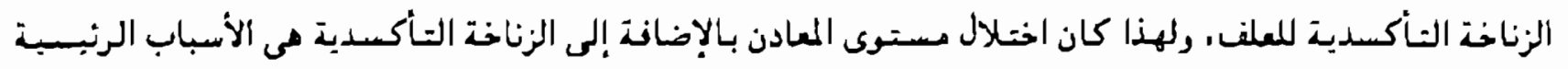
لمثيكلة. 